of vision so caused may be wrongly attributed to papilloedema. 24

Monro's and George Kellie's (1779-1829) concern with the "circulation within the head" was due to a prevailing preoccupation with the congested brain, then considered to be at the root of many cerebral disorders. Kellie's reassuring conclusion that "to whatever extent the one set of vessels is becoming overcharged to the same extent, it seems probable, is the other set voided" had a profound impact upon medical thought of the day. ${ }^{31}$ Correctly interpreted, the Monro-Kellie theorem is still a valuable adjunct to a consideration of the swollen brain.

1 Monro, A. (Secundus), Observations on the Structure and Functions of the Nervous System. Edinburgh, Creech and Johnson, 1783.

2 Reichardt, M., Deutsche Zeitschrift für Nervenheilkunde, 1905, 28, 306.

3 Brock, M., Winbelmüller, W., Pöll, W., Markakos, E., and Dietz, H., Lancet, 1972, 1, 595.

Lancet, 1972, 1, 595.
Fujita, S., Veda, T., and Yagi, M., Fournal of Neurosurgery, 1972, 37, 156.

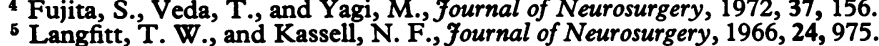
5 Langfitt, T. W., and Kassell, N. F., Fournal of Ne

7 Levine, S., and Klein, M., Archives of Pathology, 1960, 69, 544.

8 White, J. C., Brooks, J. R., Goldthwait, J. C., and Adams, R. D., Annals of Surgery, 1943, 118, 619.

- Byrom, F. B., Lancet, 1954, 2, 201.

Miller, A., Bader, R. A., and Bader, E., American fournal of Medicine, $1962,33,309$.

11 Ware, A. J., D'Agostino, A. N., and Combes, B., Gastroenterology, 1971, 61, 877.

12 Grant, D. K., Quarterly fournal of Medicine, 1953, 22, 243.

13 Jefferson, A., fournal of Neurology, Neurosurgery, and Psychiatry, 1956, 19, 21.

14 Dandy, W. E., Annals of Surgery, 1937, 106, 492.

15 Neville, B. G. R., and Wilson, J., British Medical fournal, 1970, 3, 554.

16 Knizley, H., and Noyes, $\mathbf{W}$., Archives of Internal Medicine, 1972, 129, 483

17 Marr, W. G., and Chambers, R. G., American fournal of Ophthalmology, $1961,51,605$.

18 Morrice, G., Havener, W.H., and Kapetansky, F., fournal of the American Medical Association, 1960, 173, 1802.

10 Kock-Weser, J., and Gilmore, E. B., Fournal of the American Medical Association, 1967, 200, 345.

20 Boreus, L. O., Sundstrom, B., British Medical Fournal, 1967, $2,744$.

21 Popoff, N., Weinberg, S., and Feigin, I., Neurology, 1963, 13, 101.

22 Rosomoff, H. L., and Zugibe, F. T., Archives of Neurology, 1963, 9, 26

23 Behrman, S., Neurology, 1964, 14, 236.

24 Behrman, S., Brain, 1966, 89, 1 .

25 Brain, W. R., Brain, 1925, 48, 105.

27 Galicich, J. H., and French, L. A., American Practitioner and Digest of Treatment, 1961, 12, 169.

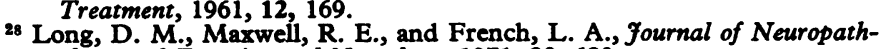
ong, D. M., Maxwell, R. E., and French, L. A.,
ology and Experimental Neurology, 1971, 30, 680 .

20 Weinstein, J. D., Toy, F. J., Jaffe, M. E., and Goldberg, H. I., Neurology, 1973, 23, 121.

${ }^{30}$ Langfitt, T. W., et al., in Brain and Blood Flow, ed. R. W. R. Russell. London, Pitman, 1971

${ }^{31}$ Kellie, G., Transactions of the Medico-Chirurgical Society of Edinburgh, $1824,1,84$.

\section{Penicillamine in the Treatment of Rheumatoid Arthritis}

Used initially in the treatment of Wilson's disease, ${ }^{12}$ penicillamine was later found to be effective in the treatment of lead poisoning, gold poisoning, cystinuria, and some other conditions. But it was its use in the treatment of rheumatoid arthritis $^{34}$ that brought it into prominence. This year a British double-blind, multicentre controlled trial ${ }^{5}$ showed that it undoubtedly benefited patients with acute, severe rheumatoid arthritis.

Thirty of 52 patients on D-penicillamine and 38 of 53 controls completed 12 months' treatment. In the penicillaminetreatment group $30 \%$ of the losses were the result of drug intolerance, while none were lost from progression of the disease. In the control group $17 \%$ of the losses were because of deterioration in the patient's clinical condition. All measurements except radiographic changes in the small joints showed greater improvement in the penicillamine-treated patients, and the improvement was usually statistically significant. Penicillamine emerged as an effective form of treatment of active rheumatoid disease.

In the treatment of rheumatoid arthritis penicillamine has many points of similarity with gold. It takes several weeks to produce its therapeutic effect, and when treatment has to be stopped prematurely the arthritic condition tends to return gradually to its previous active state.

Which cases should one treat with this drug? And what are its disadvantages? The patients who would be considered suitable for gold therapy are those who should respond to penicillamine. They are the patients with much inflammatory swelling and tenderness of the joints, a high sedimentation rate, but little or no irreversible change. The advanced, largely burnt-out crippled cases with advanced radiological changes would be unsuitable. Early rather than late advanced cases should be chosen, when physical treatment, adequate rest, and analgesic and anti-inflammatory drugs have proved to be unsatisfactory, so that the disease remains active and advances despite these measures.

A further parallel with chrysotherapy lies in the nature of the side effects penicillamine may produce. Regular blood counts and platelet counts must be done, since neutropenia, thrombocytopenia, and aplastic anaemia may occur. The urine should be checked frequently for proteinuria, for the penicillamine molecule readily combines with substances in blood and tissues to give rise to complexes which may be antigenic. Acute hypersensitivity reactions with rash and fever may appear early in treatment, and nausea, anorexia, and vomiting may be troublesome. Proteinuria may be heavy and persist for months, but like the other toxic effects of penicillamine it nearly always disappears completely on discontinuing the drug and leaves no permanent effects.

The drug is tolerated better and side effects are fewer if dosage is initially low and only slowly increased. The usual practice is to give one tablet ( $250 \mathrm{mg}$ of D-penicillamine B.P.) or two capsules (each $150 \mathrm{mg}$ of D-penicillamine hydrochloride B.P.) by mouth daily, dosage being increased by the same amount at intervals of two to three weeks or longer, until a total daily dose of 1,000 to $1,500 \mathrm{mg}$ has been reached. Treatment is then continued for 12 months or considerably longer according to tolerance and therapeutic effect. Higher dosage is needed to achieve control in some cases, lower in others. D-penicillamine is used in preference to $L$ or DL-penicillamine, which is more toxic. Its mode of action is still unknown.

Highly effective drugs have sometimes been prescribed with insufficient caution for patients with rheumatoid arthritis. Cortisone and phenylbutazone are two examples. Bad therapeutic results followed their misuse and side effects were unnecessarily frequent, usually as the result of overdosage. W. H. Lyle ${ }^{6}$ has recently drawn attention to the possibility of the same thing occurring with misuse of penicillamine. The drug seems likely to be most often used when gold salts are disliked or have proved toxic or ineffective. It would be unfortunate if this drug, which can benefit some patients, were to fail to do so through faulty prescribing.

\footnotetext{
1 Walshe, J. M., Lancet, 1956, 1, 25.

2 Walshe, J. M Lancet, 1960, 1, 18

3 Jaffe, I. A., Annals of Internal Medicine, 1964, 61, 556.

4 Jaffe, I. A., Arthritis and Rheumatism, 1970, 13, 436.

5 Multicentre Trial Group, Andrews, F. M., et al., Lancet, 1973, 1, 275.

6 Lyle, W. H., British Medical fournal, 1973, 3, 235.
} 